\title{
Clinical significance of zinc-finger E-box binding homeobox 1 mRNA levels in peritoneal washing for gastric cancer
}

\author{
NORIMITSU YABUSAKI, SUGURU YAMADA, TOSHIFUMI MURAI, MITSURO KANDA, \\ DAISUKE KOBAYASHI, CHIE TANAKA, TSUTOMU FUJII, GORO NAKAYAMA, HIROYUKI SUGIMOTO, \\ MASAHIKO KOIKE, SHUJI NOMOTO, MICHITAKA FUJIWARA and YASUHIRO KODERA
}

Department of Gastroenterological Surgery (Surgery II), Nagoya University

Graduate School of Medicine, Nagoya, Aichi 466-8550, Japan

Received September 22, 2014; Accepted November 10, 2014

DOI: $10.3892 /$ mco.2014.462

\begin{abstract}
Zinc-finger E-box binding homeobox 1 (ZEB1) is an important regulator of epithelial-to-mesenchymal transition and is associated with various types of metastasis. Gastric cancer patients often develop peritoneal carcinomatosis, of which the detection of free cancer cells in the peritoneal washes is an important predictor. We analyzed the correlation of ZEB1 mRNA levels in the peritoneal washing (pZEB1) with clinicopathological variables and survival in 107 gastric cancer patients who underwent surgery and peritoneal washing cytology. Reverse transcription-polymerase chain reaction was performed to quantify pZEB1. The patients were classified into the $\mathrm{pZEB} 1^{\text {High }}(\mathrm{n}=27)$ and the $\mathrm{pZEB1} 1^{\text {Low }}(\mathrm{n}=80)$ groups based on their pZEB1 expression. pZEB1 was statistically correlated with pathological $\mathrm{T}$ stage $(\mathrm{P}=0.03)$ and vascular involvement $(\mathrm{P}=0.03)$. At 5 years, the disease-specific survival was $36.4 \%$ for the $\mathrm{pZEB} 1^{\text {High }}$ group and $64.7 \%$ for the $\mathrm{pZEB} 1^{\text {Low }}$ group $(\mathrm{P}=0.02)$, whereas the disease-free survival rate was $46.9 \%$ for the $\mathrm{pZEB} 1^{\text {High }}$ group and $83.0 \%$ for the $\mathrm{pZEB} 1^{\text {Low }}$ group $(\mathrm{P}=0.03)$. When subclassified into 4 categories based on washing cytology and pZEB1, survival was significantly lower in the $\mathrm{pZEB} 1^{\text {High }}$ compared to the $\mathrm{pZEB} 1^{\text {Low }}$ group (cytology-negative group, $\mathrm{P}=0.01$; cytology-positive group, $\mathrm{P}=0.13$ ). Therefore, $\mathrm{pZEB} 1$ may add valuable information to conventional peritoneal washing cytology as a prognostic determinant in gastric cancer.
\end{abstract}

Correspondence to: Dr Suguru Yamada, Department of Gastroenterological Surgery (Surgery II), Nagoya University Graduate School of Medicine, 65 Tsurumai-cho, Showa-ku, Nagoya, Aichi 466-8550, Japan

E-mail:suguru@med.nagoya-u.ac.jp

Key words: zinc-finger E-box binding homeobox 1, peritoneal washing, epithelial-to-mesenchymal transition, gastric cancer

\section{Introduction}

Although the survival of patients with gastric cancer has improved due to the recent advances in treatment, the prognosis of locally advanced or metastatic cancer remains poor (1-3). A proportion of the patients develop recurrences even after curative resection, possibly reflecting the presence of residual cancer cells and micrometastases that had not been detected by the currently available diagnostic technology $(4,5)$. Therefore, the accurate evaluation of microscopic residual disease may lead to more appropriate therapeutic strategies and improvement in survival.

Epithelial-to-mesenchymal transition (EMT) is a critical process during which the adhesion and migration properties of cancer cells change dramatically (6,7). During EMT, the cells lose epithelial polarity and acquire a spindle-shaped, highly motile fibroblastoid phenotype. Various transcription factors are known to trigger EMT (8-10), including zinc-finger E-box binding homeobox 1 (ZEB1), a central EMT mediator $(11,12)$. ZEB1 reportedly affects cancer progression by regulating EMT in gastric, breast, prostate, ovarian and colorectal cancers (13-20).

In gastric cancer, carcinoembryonic antigen (CEA) mRNA levels in peritoneal washing have been reported to be potential predictors of peritoneal recurrence $(21,22)$. Kodera et al reported that the combination of CEA and cytokeratin-20 in peritoneal washes may more accurately predict prognosis (23). ZEB1 expression has also been recently reported as a novel biomarker in cancer tissue that may independently predict overall survival $(13,14,24)$. We recently reported on a significant correlation between ZEB1 expression and diffuse phenotype in gastric cancer (24). Okugawa et al reported that ZEB1 was an independent predictor of peritoneal dissemination in gastric cancer patients and was expressed in disseminated cancer cells in the peritoneum in the same pattern as that seen in the primary lesions (13). Therefore, we hypothesized that the ZEB1 mRNA levels in peritoneal washing (pZEB1) in conjunction with peritoneal washing cytology may predict intraperitoneal recurrence and prognosis.

This study investigated the association of pZEB1 with clinicopathological parameters and prognosis and the potential of pZEB1 as a predictive marker. To the best of our knowledge, 
this is the first report on the clinical implication of pZEB1 in gastric cancer.

\section{Materials and methods}

Patients. We enrolled 107 consecutive gastric cancer patients who underwent surgical procedures that included collection of peritoneal washing samples at the left subphrenic area at the beginning of surgery, between January, 2005 and August, 2010 at the Department of Gastroenterological Surgery, Nagoya University Hospital, Nagoya, Aichi, Japan. All the patients had histologically confirmed gastric cancer. Of the 107 patients, 4 had received chemotherapy prior to surgery, 2 of whom achieved a complete response. All the patients had been staged according to the Union for International Cancer Control staging criteria for gastric cancer (7th edition, 2009) as follows: 2 patients had stage $0 ; 12$ had stage IA; 11 had stage IB; 7 had stage IIA; 12 had stage IIB; 8 had stage IIIA; 10 had stage IIIB; 10 had stage IIIB; 10 had stage IIIC; and 35 had stage IV disease. Overall, 72 patients underwent curative resection, 35 patients underwent non-curative resection, of whom 2 patients did not receive gastrectomy due to disseminated cancer. All the patients underwent gastrectomy with D2 lymphadenectomy when potentially curative R0 resection was planned. The median follow-up period was 41.9 months (range, 1-106 months). This study was approved by the Ethics Committee of our hospital and signed informed consent was obtained from all the participating patients.

Peritoneal washes. At the beginning of each surgery, 100-200 ml saline was introduced into the left subphrenic area and aspirated soon after gentle stirring. Half of each fluid sample was sent for routine cytopathology with conventional Papanicolaou and Giemsa staining, whereas the other half was used to measure ZEB1 mRNA levels. The sample was centrifuged at $540 \mathrm{x} \mathrm{g}$ for $5 \mathrm{~min}$ to collect intact cells, rinsed with phosphate-buffered saline, dissolved in ISOGEN-LS RNA extraction buffer (Nippon Gene, Tokyo, Japan) and stored immediately in liquid nitrogen at $-80^{\circ} \mathrm{C}$ until analysis.

Reverse transcription-quantitative polymerase chain reaction $(R T-q P C R)$. Total RNA was isolated from each of the frozen samples with the RNeasy mini kit (Qiagen, Hilden, Germany) according to manufacturer's instructions. cDNA was synthesized using the QuantiTect Reverse Transcription kit (Qiagen, Hilden, Germany) and amplified by PCR primers as follows: ZEB1: 5'-TGCACTGAGTGTGGAAAAGC-3' (forward) and 5'-TGGTGATGCTGAAAGAGACG-3' (reverse), which amplify a 237-bp product. RNA expression was determined using the real-time quantitative PCR method. To quantify and demonstrate the integrity of the isolated RNA, glyceraldehyde-3-phophate dehydrogenase was also analyzed with RT-qPCR using the primer set 5'-AACGGCTCCGGCATGTGCAA-3' (forward) and 5'-GGCTCCTGTGCAGAGAAAGC-3' (reverse). All the PCR reactions were performed as follows: 1 cycle at $50^{\circ} \mathrm{C}$ for $2 \mathrm{~min}, 1$ cycle at $95^{\circ} \mathrm{C}$ for $10 \mathrm{~min}$, followed by 40 cycles at $95^{\circ} \mathrm{C}$ for $15 \mathrm{sec}$ and at $60^{\circ} \mathrm{C}$ for $60 \mathrm{sec}$. Real-time detection of the emission intensity of SYBR-Green was performed with an ABI prism 7000 Sequence Detector (Perkin-Elmer
Table I. Patient characteristics.

Characteristics

Patient no.

\begin{tabular}{lr} 
Age, years & \\
(mean \pm SD) & $63 \pm 13.5$ \\
Gender & \\
Male & 83 \\
Female & 24 \\
Operative method & \\
TGX & 45 \\
DGX & 57 \\
PGX & 3 \\
Gastrojejunostomy & 1 \\
Exploratory laparotomy & 1 \\
UICC stage & \\
0 & 2 \\
IA & 12 \\
IB & 11 \\
IIA & 7 \\
IIB & 12 \\
IIIA & 8 \\
IIIB & 10 \\
IIIC & 10 \\
IV & 35 \\
\hline
\end{tabular}

SD, standard deviation; DGX, distal gastrectomy; PGX, proximal gastrectomy; TGX, total gastrectomy; UICC, Union for International Cancer Control.

Applied Biosystems, Foster City, California, USA). qPCR was performed at least 3 times, including a negative no-template control.

Statistical analysis. Correlations between pZEB1 expression and clinicopathological variables were analyzed by the $\chi^{2}$ and Fisher's exact tests. Disease-specific survival (DSS) and disease-free survival (DFS) were calculated using the Kaplan-Meier method and differences in survival curves were analyzed using the log-rank test. The Cox proportional hazards model was used for multivariate analysis, after relevant prognostic variables had been defined by univariate analysis. Data were analyzed using JMP v10 software (JMP, SAS Institute, Cary, North Carolina, USA). $\mathrm{P}<0.05$ was considered to indicate statistically significant differences.

\section{Results}

Patient demographics. The 107 subjects in this study included 83 men and 24 women, with a median age of 63 years (range, 20-84 years) (Table I). Of the 107 patients, 45 underwent total gastrectomy, 57 distal gastrectomy, 3 proximal gastrectomy, 1 gastrojejunostomy and 1 exploratory laparotomy.

Correlation between pZEBI and clinicopathological factors. pZEB1 was technically detectable in all 107 patients by qPCR. 
Table II. Correlation between clinicopathological variables and pZEB1 expression in patients with gastric cancer.

\begin{tabular}{|c|c|c|c|}
\hline Variables & $\begin{array}{c}\text { pZEB }^{\text {Low }} \\
(\mathrm{n}=80)\end{array}$ & $\begin{array}{c}\text { pZEB1 } 1^{\text {High }} \\
(n=27)\end{array}$ & P-value \\
\hline Gender & & & 0.30 \\
\hline Male & 64 & 19 & \\
\hline Female & 16 & 8 & \\
\hline Age, years & & & 0.61 \\
\hline$\geq 65^{\circ}$ & 46 & 14 & \\
\hline$<65$ & 34 & 13 & \\
\hline Tumor size, $\mathrm{cm}$ & & & 0.78 \\
\hline$\geq 5$ & 39 & 13 & \\
\hline$<5$ & 41 & 12 & \\
\hline Histological type & & & 0.38 \\
\hline Diffuse & 52 & 20 & \\
\hline Intestinal & 28 & 7 & \\
\hline Pathological T stage & & & $0.03^{\mathrm{a}}$ \\
\hline $\mathrm{pT} 1 / 2$ & 30 & 4 & \\
\hline $\mathrm{pT} 3 / 4$ & 50 & 23 & \\
\hline Vascular involvement & & & $0.03^{\mathrm{a}}$ \\
\hline Present & 37 & 18 & \\
\hline Absent & 42 & 7 & \\
\hline Lymphatic vessel involvement & & & 0.20 \\
\hline Present & 64 & 23 & \\
\hline Absent & 15 & 2 & \\
\hline Lymph node metastasis & & & 0.45 \\
\hline Present & 52 & 19 & \\
\hline Absent & 28 & 7 & \\
\hline Liver metastasis & & & 0.16 \\
\hline Present & 7 & 5 & \\
\hline Absent & 73 & 22 & \\
\hline Peritoneal dissemination & & & 0.22 \\
\hline Present & 10 & 6 & \\
\hline Absent & 70 & 21 & \\
\hline Peritoneal washing cytology & & & 0.46 \\
\hline Present & 18 & 8 & \\
\hline Absent & 62 & 19 & \\
\hline TNM stage & & & 0.16 \\
\hline $\mathrm{I} / \mathrm{II}$ & 36 & 8 & \\
\hline III/IV & 44 & 19 & \\
\hline
\end{tabular}

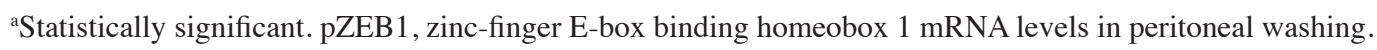

The values ranged from $3.0 \times 10^{-6}$ to $7.0 \times 10^{-3} \mu \mathrm{g} / \mu \mathrm{l}$ (median, $\left.1.2 \times 10^{-} \mu \mathrm{g} / \mu \mathrm{l}\right)$. The $\mathrm{pZEB} 1$ cut-off point was set at the top quartile, which was $3.5 \times 10^{-4} \mu \mathrm{g} / \mu 1$. Accordingly, patients with low pZEB1 expression $\left(<3.5 \times 10^{-4} \mu \mathrm{g} / \mu \mathrm{l}\right)$ were assigned to the pZEB1 ${ }^{\text {Low }}$ group $(n=80)$, whereas those with high expression $\left(\geq 3.5 \times 10^{-4} \mu \mathrm{g} / \mu \mathrm{l}\right)$ were assigned to the $\mathrm{pZEB} 1^{\text {High }}$ group $(\mathrm{n}=27)$.

The analysis of pZEB1 expression and various clinicopathological factors (Table II) revealed that pZEB1 was correlated with pathological $\mathrm{T}$ stage $(\mathrm{P}=0.03)$ and vascular involvement
$(\mathrm{P}=0.03)$, but not with gender, age, tumor size, histological type, lymphatic vessel involvement, lymph node metastasis, liver metastasis, peritoneal dissemination, peritoneal washing cytology, or TNM stage.

Patient survival by pZEB1 expression. The survival curves of patients with gastric cancer by pZEB1 expression are presented in Fig. 1. DSS was significantly lower in patients with $\mathrm{pZEB} 1^{\mathrm{High}}$ expression compared to those with $\mathrm{pZEB} 1^{\mathrm{Low}}$ expression. The 

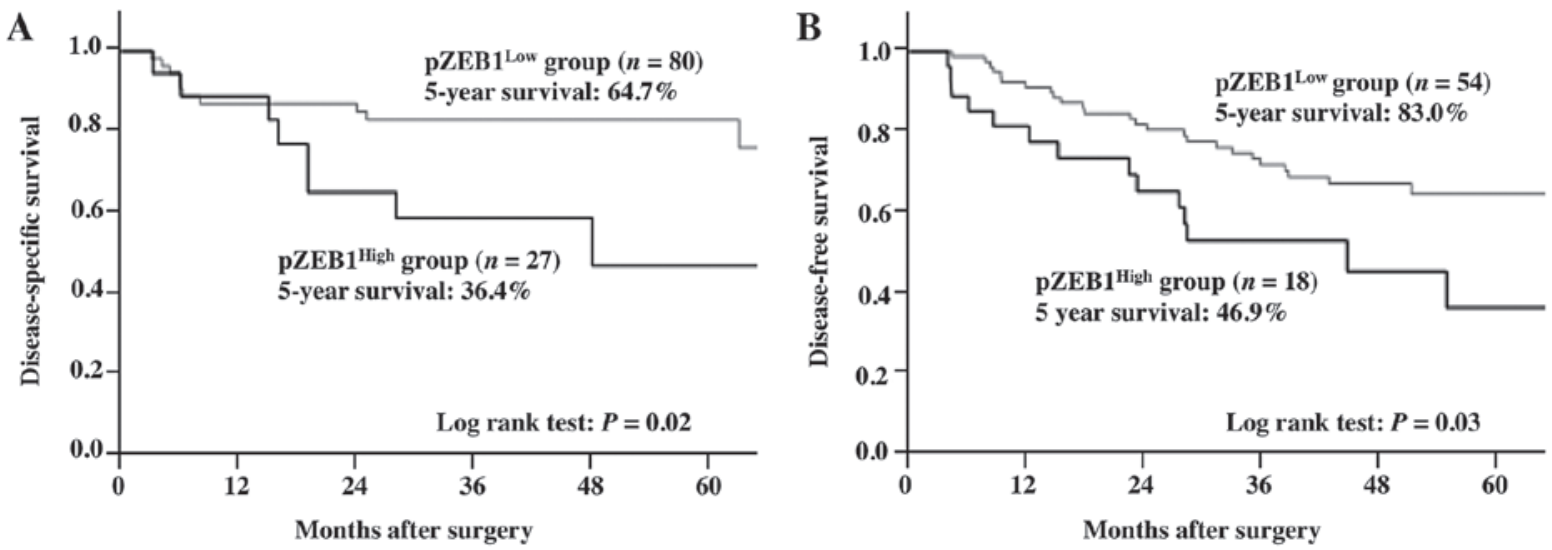

Number at risk

\begin{tabular}{cccccc}
\multicolumn{2}{c}{ pZEB 1 1 } & Lw & group \\
80 & 72 & 60 & 51 & 32 & 17 \\
pZEB1 $^{\text {High }}$ group & & & & \\
27 & 21 & 17 & 11 & 6 & 4
\end{tabular}

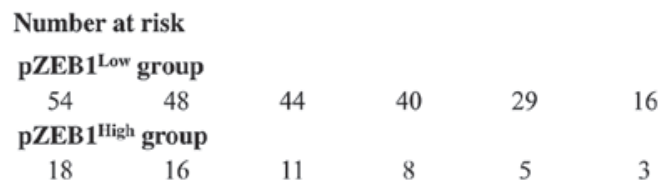

Figure 1. Survival curves for gastric cancer patients by pZEB1 expression status. (A) Disease-specific survival; (B) disease-free survival. The patients with pZEB1 ${ }^{\text {High }}$ expression exhibited a significantly poorer prognosis compared to those with pZEB1 ${ }^{\text {Low }}$ expression (A) $\mathrm{P}=0.02$, (B) $\mathrm{P}=0.03$, log-rank test. pZEB1, zinc-finger E-box binding homeobox 1 mRNA levels in peritoneal washing.

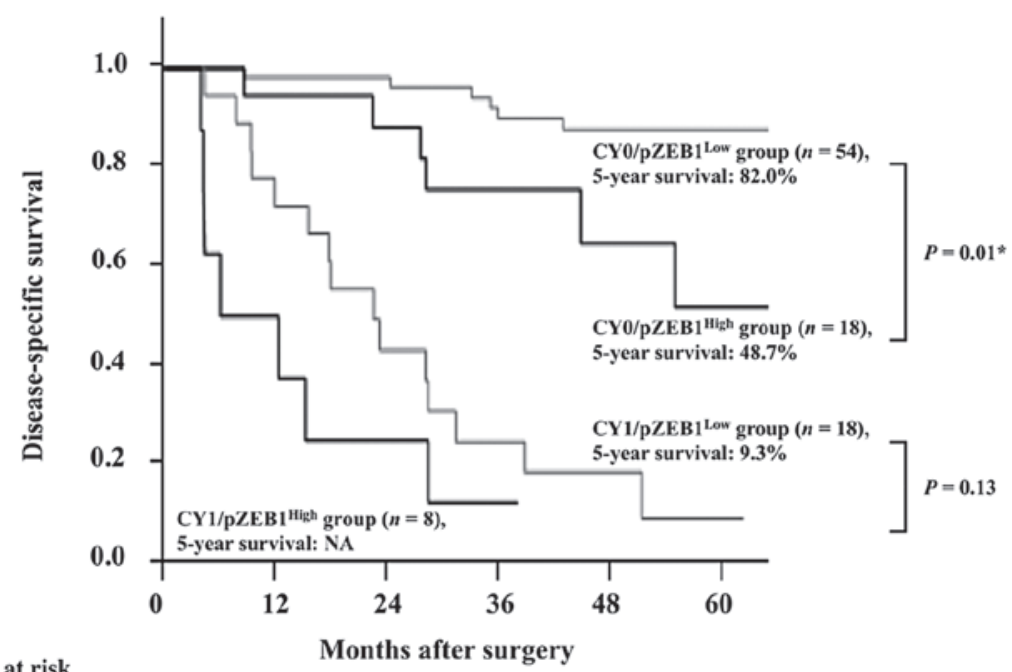

\begin{tabular}{lcccccc} 
Number at risk & \multicolumn{5}{c}{ Months after surgery } \\
CY1/pZEB1 1 $1^{\text {Low }}$ & 54 & 54 & 51 & 44 & 31 & 17 \\
CY0/pZEB1 $^{\text {High }}$ & 18 & 17 & 15 & 10 & 7 & 4 \\
CY1/pZEB1 $1^{\text {Low }}$ & 18 & 14 & 8 & 5 & 4 & 2 \\
CY1/pZEB1 ${ }^{\text {High }}$ & 8 & 5 & 3 & 1 & &
\end{tabular}

Figure 2. Survival curves for gastric cancer patients based on washing cytology and pZEB1 expression. The patients were subclassified into 4 types based on washing cytology and pZEB1 expression. Disease-specific survival was significantly lower in patients with pZEB1 ${ }^{\text {High }}$ expression compared to those with pZEB1 $^{\text {Low }}$ expression. (CY0 group, $\mathrm{P}=0.01$; $\mathrm{CY} 1$ group, $\mathrm{P}=0.13$ ). pZEB1, zinc-finger $\mathrm{E}-$ box binding homeobox $1 \mathrm{mRNA}$ levels in peritoneal washing; $\mathrm{CY0}$, negative cytology; CY1, positive cytology; NA, not applicable.

5-year DSS was $36.4 \%$ in the pZEB1 ${ }^{\text {High }}$ group and $64.7 \%$ in the $\mathrm{pZEB} 1^{\mathrm{Low}}$ group $(\mathrm{P}=0.02)$, whereas the 5 -year DFS was $46.9 \%$, in the $\mathrm{pZEB} 1^{\mathrm{High}}$ group and $83.0 \%$ in the $\mathrm{pZEB} 1^{\text {Low }}$ group $(\mathrm{P}=0.03)$.

The patients were next subclassified into 4 groups according to negative or positive peritoneal washing cytology (CY0 and CY1, respectively) as follows: CY0/pZEB1 ${ }^{\text {Low }}, \mathrm{CY} 0 / \mathrm{pZEB} 1^{\mathrm{High}}$, $\mathrm{CY} 1 / \mathrm{pZEB} 1^{\text {Low }}$ and $\mathrm{CY} 1 / \mathrm{pZEB} 1^{\text {High }}$. In the CY0 group, DSS was significantly lower in the pZEB1 ${ }^{\text {High }}$ group compared to that in the $\mathrm{pZEB} 1^{\mathrm{Low}}$ group. The 5-year survival rate was $48.7 \%$ in the CY0/pZEB1 $1^{\text {High }}$ group and $82.0 \%$ in the CY0/pZEB1 ${ }^{\text {Low }}$ group ( $\mathrm{P}=0.01)$. In the $\mathrm{CY} 1$ group, DSS was also lower among patients with $\mathrm{pZEB} 1^{\mathrm{High}}$ expression compared to those with pZEB1 ${ }^{\text {Low }}$ expression. The 5-year survival rate was $0 \%$ in the $\mathrm{CY} 1 / \mathrm{pZEB} 1^{\text {High }}$ group and $9.3 \%$ in the CY1/pZEB1 ${ }^{\text {Low }}$ group $(\mathrm{P}=0.13)$ (Fig. 2).

pZEB1 as a predictor of recurrence after surgery. Among the 18 patients who developed recurrences after surgery, 10 patients had pZEB1 ${ }^{\text {Low }}$ expression and 8 had $\mathrm{pZEB} 1^{\text {High }}$ expression. The recurrence rate in the $\mathrm{pZEB} 1^{\mathrm{High}}$ group $(8 / 27)$ was significantly higher compared to that in the $\mathrm{pZEB1} 1^{\mathrm{Low}}$ group $(10 / 80 ; \mathrm{P}=0.03$, 
Table III. Correlation of pZEB1 expression status with recurrence of gastric cancer and recurrence site.

A, Correlation of pZEB1 expression with recurrence

\begin{tabular}{lccc}
\hline Recurrence & $\begin{array}{c}\mathrm{pZEB}^{\text {Low }} \\
(\mathrm{n}=54)\end{array}$ & $\begin{array}{c}\mathrm{pZEB} 1^{\text {High }} \\
(\mathrm{n}=18)\end{array}$ & $0.03^{\mathrm{a}}$ \\
\hline Yes & 10 & 8 & 10 \\
No & 44 & $\mathrm{P}-\mathrm{value}$ \\
\hline
\end{tabular}

$\mathrm{B}$, Correlation of pZEB1 expression with recurrence site

\begin{tabular}{lcc}
\hline Recurrence site & No. & pZEB1 \\
\hline Lymph nodigh & $4 / 2$ \\
Peritoneum & 6 & $2 / 4$ \\
Liver & 6 & $3 / 2$ \\
Lung & 5 & $1 / 0$
\end{tabular}

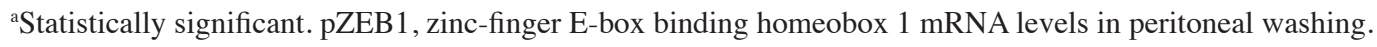

Table IV. Characteristics of patients with $\mathrm{pZEB} 1^{\text {High }}$ expression excluding those with stage IV disease.

\begin{tabular}{|c|c|c|c|c|c|c|c|}
\hline Patients & Age (yrs) & Gender & DFS & Recurrence site & T stage & Metastasis $^{\mathrm{a}}$ & Histology \\
\hline 1 & 62 & $\mathrm{~F}$ & 48 & Peritoneum & $\mathrm{T} 4 \mathrm{a}$ & N3a & Diffuse \\
\hline 2 & 60 & $\mathrm{~F}$ & 28 & Peritoneum & $\mathrm{T} 4 \mathrm{a}$ & N1 & Diffuse \\
\hline 3 & 55 & M & 3.2 & Peritoneum & $\mathrm{T} 4 \mathrm{a}$ & No & Diffuse \\
\hline 4 & 55 & M & 19 & Peritoneum & $\mathrm{T} 2$ & No & Diffuse \\
\hline 5 & 63 & M & 15 & Liver & T3 & N3b & Intestinal \\
\hline 6 & 61 & M & 6 & Liver & $\mathrm{T} 3$ & $\mathrm{~N} 2$ & Intestinal \\
\hline 7 & 71 & M & 16 & Lymph node & $\mathrm{T} 3$ & $\mathrm{~N} 2$ & Diffuse \\
\hline 8 & 75 & $\mathrm{~F}$ & 19 & Lymph node & $\mathrm{T} 4 \mathrm{a}$ & N3a & Diffuse \\
\hline 9 & 56 & M & 70 & None & $\mathrm{T} 3$ & N1 & Diffuse \\
\hline 10 & 70 & M & 9.5 & None & T3 & No & Intestinal \\
\hline 11 & 71 & $\mathrm{~F}$ & 69 & None & $\mathrm{T} 2$ & No & Diffuse \\
\hline 12 & 67 & M & 27 & None & T1a & No & Intestinal \\
\hline 13 & 52 & M & 31 & None & T3 & No & Diffuse \\
\hline 14 & 72 & M & 45 & None & $\mathrm{T} 4 \mathrm{a}$ & N1 & Diffuse \\
\hline 15 & 74 & M & 35 & None & $\mathrm{T} 1 \mathrm{~b}$ & No & Intestinal \\
\hline 16 & 65 & M & 58 & None & $\mathrm{T} 4 \mathrm{a}$ & N1 & Intestinal \\
\hline 17 & 35 & $\mathrm{~F}$ & 50 & None & $\mathrm{T} 4 \mathrm{a}$ & $\mathrm{N} 2$ & Diffuse \\
\hline 18 & 59 & M & 43 & None & $\mathrm{T} 2$ & No & Diffuse \\
\hline
\end{tabular}

${ }^{a}$ Metastatic lymph nodes. pZEB1, zinc-finger E-box binding homeobox $1 \mathrm{mRNA}$ levels in peritoneal washing; DFS, disease-free survival (in months).

Table IIIA). Of these 18 patients 6 developed lymph node metastases, 6 peritoneal metastases, 5 liver metastases and 1 lung metastasis. Of the 6 patients with recurrent peritoneal metastases, 4 were in the pZEB1 ${ }^{\text {High }}$ group (Table IIIB).

The characteristics of the 18 patients with $\mathrm{pZEB} 1^{\mathrm{High}}$ and CY0, excluding those with stage IV disease, are summarized in Table IV. Among these, 8 patients ultimately developed recurrent metastases ( 4 in the peritoneum, 2 in the liver and 2 in the lymph nodes).
Prognostic factors of gastric cancer patients by univariate and multivariate analysis. The univariate analysis using the Cox proportional hazards model identified 9 prognostic factors, namely tumor size, T stage, histological type, lymph node metastasis, lymphatic vessel involvement, vascular involvement, peritoneal metastasis, liver metastasis and pZEB1 expression (Table V). However, in the multivariate analysis of these parameters, pZEB1 was not identified as an independent predictor of DSS. 
Table V. Univariate and multivariate analysis of clinicopathological factors for disease-specific survival.

\begin{tabular}{|c|c|c|c|c|c|c|}
\hline \multirow[b]{2}{*}{ Variables } & \multicolumn{3}{|c|}{ Univariate analysis } & \multicolumn{3}{|c|}{ Multivariate analysis } \\
\hline & HR & $95 \% \mathrm{CI}$ & P-value & $\mathrm{HR}$ & $95 \% \mathrm{CI}$ & P-value \\
\hline Gender (female) & 1.3 & $0.6-2.5$ & 0.52 & & & \\
\hline Age ( $\geq 65$ years) & 1.0 & $0.6-2.0$ & 0.89 & & & \\
\hline Tumor size $(\geq 5 \mathrm{~cm})$ & 2.3 & $1.2-4.6$ & $0.01^{\mathrm{a}}$ & 1.1 & $0.5-2.5$ & 0.76 \\
\hline Pathological T stage (pT3/4) & 8.4 & $3.0-34.9$ & $<0.001^{\mathrm{a}}$ & 4.4 & $1.1-24.8$ & $0.04^{\mathrm{a}}$ \\
\hline Histological type (diffuse) & 2.3 & $1.1-5.4$ & $0.02^{\mathrm{a}}$ & 1.3 & $0.5-3.5$ & 0.57 \\
\hline Lymph node metastasis & 4.2 & $1.8-12.4$ & $<0.001^{\mathrm{a}}$ & 2.2 & $0.7-10.1$ & 0.22 \\
\hline Lymphatic vessel involvement & 4.7 & $1.4-28.9$ & $0.008^{\mathrm{a}}$ & 0.4 & $0.05-3.8$ & 0.40 \\
\hline Vascular involvement & 3.9 & $1.9-8.7$ & $<0.001^{\mathrm{a}}$ & 2.0 & $0.8-5.3$ & 0.13 \\
\hline Peritoneal metastasis & 10.6 & $5.2-21.2$ & $<0.001^{\mathrm{a}}$ & 4.1 & $1.8-9.4$ & 0.001 \\
\hline Liver metastasis & 5.2 & $2.2-11.1$ & $<0.001^{\mathrm{a}}$ & 2.9 & $0.9-7.9$ & 0.06 \\
\hline pZEB $1^{\text {High }}$ & 2.1 & $1.1-4.0$ & $0.03^{\mathrm{a}}$ & 1.0 & $0.4-2.1$ & 0.98 \\
\hline
\end{tabular}

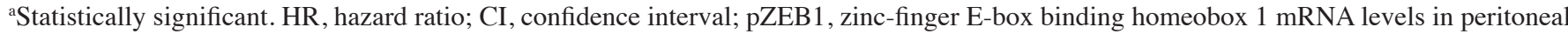
washing.

\section{Discussion}

EMT is a process through which epithelial cells attain fibroblastic characteristics, which enable them to invade neighboring tissues $(25,26)$. ETM is regulated by several transcription factors, including Snail, Slug, Twist, CarB-box-binding factor, mesenchyme forkhead 1, Krüppel-like factor and ZEB1 (26-29).

ZEB1 is reportedly a key player in cancer progression (17,30-32). In particular, high expression of ZEB1 in endometrial and colorectal cancers and hepatocellular carcinoma has been associated with poor prognosis $(15,33,34)$. In gastric cancer, ZEB1 expression in cancer tissues has been identified as an independent prognostic factor $(13,14)$. We have also reported a correlation between high ZEB1 expression and diffuse pathological cancer type (24). However, the diffuse type is a known risk factor for peritoneal recurrence in gastric cancer, which supports the findings of Okugawa et al (13), who reported that high ZEB1 expression is an independent factor for peritoneal carcinomatosis.

Comparisons of the expression of EMT markers in the primary tumor and corresponding lymph node metastases have been performed for several cancer types $(35,36,37)$. These studies demonstrated that the expression of EMT markers in mature metastatic lymph nodes was lower compared to that in the primary lesions; therefore it was hypothesized that mesenchymal-to-epithelial transition (MET), the reverse phenomenon of EMT, may occur at secondary metastatic sites before the metastasized cells develop into clinically significant metastatic lesions. However, Okugawa et al (13) observed through immunostaining that ZEB1 expression in the peritoneal metastatic sites exhibited the same pattern as that observed in the primary lesions. The role of EMT and MET in the development of peritoneal metastasis may be different from that of nodal metastasis and it may be of value to investigate the EMT status of intraperitoneal cancer cells that likely develop into visible peritoneal deposits. To the best of our knowledge, there are no available studies investigating pZEB1 in gastric cancer patients.

The major finding in this study was that pZEB1 expression was significantly associated with DSS and DFS in patients with gastric cancer. Furthermore, pZEB1 may be a more sensitive diagnostic tool for poor prognosis compared to conventional peritoneal washing cytology, as the RT-qPCR more sensitively detects intraperitoneal free cancer cells and also because positive pZEB1 reflects the capability of the primary tumor to disseminate ZEB1-positive mesenchymally transformed cells into the peritoneal cavity as well as through the hematogeneous and lymphatic metastatic pathways. Although ZEB1 expression in the primary lesion is already known as an independent prognostic factor $(13,14,24)$, pZEB1 expression may also represent a novel marker of a poorer prognosis.

However, our results failed to demonstrate statistical correlations between pZEB1 and peritoneal dissemination and peritoneal recurrence. As stated above, although local ZEB1 production by cancer cells in the peritoneal cavity is the most important factor in pZEB1 expression, the primary pZEB1-high tumor may disseminate metastatic and ZEB1-producing carcinoma cells to any other sites in the body, leading to various other types of metastasis and consequent cancer-related death. Thus, pZEB1 may be correlated with poor prognosis, but not necessarily with peritoneal dissemination. There is also a possibility that a proportion of the patients did actually harbor peritoneal recurrence, but its manifestation was preceded by other types of metastasis that were clinically more relevant. Further investigation is required to elucidate the mechanisms underlying pZEB1 expression in a large population with a long-term follow-up.

In conclusion, pZEB1 may be a predictive marker for poor prognosis or tumor aggressiveness in gastric cancer, similar to ZEB1 expression in primary lesions. pZEB1 may add valuable information to conventional peritoneal washing cytology and, thus, help with the selection of candidates for more aggressive chemotherapies. 


\section{References}

1. Macdonald JS, Smalley SR, Benedetti J, et al: Chemoradiotherapy after surgery compared with surgery alone for adenocarcinoma of the stomach or gastroesophageal junction. N Engl Med 345: 725-730, 2001

2. Cunningham D, Allum WH, Stenning SP, et al: Perioperative chemotherapy versus surgery alone for resectable gastroesophageal cancer. N Engl Med 355: 11-20, 2006.

3. Sakuramoto S, Sasako M, Yamaguchi T, et al: Adjuvant chemotherapy for gastric cancer with S-1, an oral fluoropyrimidine. N Engl Med 357: 1810-1820, 2007.

4. Allum W, Garofalo A, Degiuli M and Schuhmacher C: The first European Union Network of Excellence for Gastric Cancer conference, Rome, Italy, April 2008. Gastric Cancer 12: 56-65, 2009.

5. Yonemura Y, Elnemr A, Endou Y, et al: Multidisciplinary therapy for treatment of patients with peritoneal carcinomatosis from gastric cancer. World J Gastrointest Oncol 2: 85-97, 2010.

6. Thiery JP: Epithelial-mesenchymal transitions in tumour progression. Nat Rev Cancer 2: 442-454, 2002.

7. Gotzmann J, Mikula M, Eger A, et al: Molecular aspects of epithelial cell plasticity: implications for local tumor invasion and metastasis. Mutat Res 566: 9-20, 2004

8. Cavallaro U and Christofori G: Cell adhesion and signalling by cadherins and Ig-CAMs in cancer. Nature Rev Cancer 4: $118-132,2004$

9. Tomita K, van Bokhoven A, van Leenders GJ, et al: Cadherin switching in human prostate cancer progression. Cancer Res 60: 3650-3654, 2000.

10. Rieger-Christ KM, Cain JW, Braasch JW, et al: Expression of classic cadherins type I in urothelial neoplastic progression. Hum Pathol 32: 18-23, 2001.

11. Christiansen JJ and Rajasekaran AK: Reassessing epithelial to mesenchymal transition as a prerequisite for carcinoma invasion and metastasis. Cancer Res 66: 8319-8326, 2006.

12. Klymkowsky MW and Savagner P: Epithelial-mesenchymal transition: a cancer researcher's conceptual friend and foe. Am J Pathol 174: 1588-1593, 2009.

13. Okugawa Y, Toiyama Y, Tanaka K, et al: Clinical significance of zinc finger E-box binding homeobox 1 (ZEB1) in human gastric cancer. J Surg Oncol 106: 280-285, 2012.

14. Jia B, Liu H, Kong Q, et al: Overexpression of ZEB1 associated with metastasis and invasion in patients with gastric carcinoma. Mol Cell Biochem 366: 223-229, 2012.

15. Zhang GJ, Zhou T, Tian HP, et al: High expression of ZEB1 correlates with liver metastasis and poor prognosis in colorectal cancer. Oncol Lett 5: 564-568, 2013.

16. Spaderna S, Schmalhofer O, Hlubek F, et al: A transient, EMT-linked loss of basement membranes indicates metastasis and poor survival in colorectal cancer. Gastroenterology 131: 830-840, 2006

17. Eger A, Aigner K, Sonderegger S, et al: DeltaEF1 is a transcriptional repressor of E-cadherin and regulates epithelial plasticity in breast cancer cells. Oncogene 24: 2375-2385, 2005.

18. Ohira T, Gemmill RM, Ferguson K, et al: WNT7a induces E-cadherin in lung cancer cells. Proc Natl Acad Sci USA 100: 10429-10434, 2003 .

19. Chua HL, Bhat-Nakshatri P, Clare SE, et al: NF-kappaB represses E-cadherin expression and enhances epithelial to mesenchymal transition of mammary epithelial cells: potential involvement of ZEB-1 and ZEB-2. Oncogene 26: 711-724, 2007.

20. Graham TR, Zhau HE, Odero-Marah VA, et al: Insulin-like growth factor-I-dependent up-regulation of ZEB1 drives epithelial-to-mesenchymal transition in human prostate cancer cells. Cancer Res 68: 2479-2488, 2008.
21. Abe N, Watanabe T, Toda $\mathrm{H}$, et al: Prognostic significance of carcinoembryonic antigen levels in peritoneal washes in patients with gastric cancer. Am J Surg 181: 356-361, 2001.

22. Ito S, Nakanishi H, Kodera Y, et al: Prospective validation of quantitative CEA mRNA detection in peritoneal washes in gastric carcinoma patients. Br J Cancer 93: 986-992, 2005.

23. Kodera Y, Nakanishi H, Ito S, et al: Prognostic significance of intraperitoneal cancer cells in gastric carcinoma: detection of cytokeratin $20 \mathrm{mRNA}$ in peritoneal washes, in addition to detection of carcinoembryonic antigen. Gastric Cancer 8: 142-148, 2005.

24. Murai T, Yamada S, Fuchs BC, et al: Epithelial-to-mesenchymal transition predicts prognosis in clinical gastric cancer. J Surg Oncol 109: 684-689, 2014.

25. Schmalhofer O, Brabletz $\mathrm{S}$ and Brabletz T: E-cadherin, beta-catenin and ZEB1 in malignant progression of cancer. Cancer Metastasis Rev 28: 151-166, 2009.

26. De Wever O, Pauwels P, De Craene B, et al: Molecular and pathological signatures of epithelial-mesenchymal transitions at the cancer invasion front. Histochem Cell Biol 130: 481-494, 2008.

27. Waldmann J, Feldmann G, Slater EP, et al: Expression of the zinc-finger transcription factor Snail in adrenocortical carcinoma is associated with decreased survival. Br J Cancer 99: 1900-1907, 2008.

28. Iwatsuki M, Mimori K, Yokobori T, et al: Epithelial-mesenchymal transition in cancer development and its clinical significance. Cancer Sci 101: 293-299, 2010.

29. Rosivatz E, Becker I, Specht K, et al: Differential expression of the epithelial-mesenchymal transition regulators Snail, SIP1 and Twist in gastric cancer. Am J Pathol 161: 1881-1891, 2002.

30. Spaderna S, Schmalhofer O, Wahlbuhl M, et al: The transcriptional repressor ZEB1 promotes metastasis and loss of cell polarity in cancer. Cancer Res 68: 537-544, 2008.

31. Drake JM, Strohbehn G, Bair TB, et al: ZEB1 enhances transendothelial migration and represses the epithelial phenotype of prostate cancer cells. Mol Biol Cell 20: 2207-2217, 2009.

32. Takeyama Y, Sato M, Horio M, et al: Knockdown of ZEB1, a master epithelial-to-mesenchymal transition (EMT) gene, suppresses anchorage-independent cell growth of lung cancer cells. Cancer Lett 296: 216-224, 2010.

33. Singh M, Spoelstra NS, Jean A, et al: ZEB1 expression in type I vs type II endometrial cancers: a marker of aggressive disease. Mod Pathol 21: 912-923, 2008.

34. Zhou YM, Cao L, Li B, et al: Clinicopathological significance of ZEB1 protein in patients with hepatocellular carcinoma. Ann Surg Oncol 19: 1700-1706, 2012.

35. Kurahara H, Takao S, Maemura K, et al: Epithelial-mesenchymal transition and mesenchymal-epithelial transition via regulation of ZEB-1 and ZEB-2 expression in pancreatic cancer. J Surg Oncol 105: 655-661, 2012.

36. Toll A, Masferrer E, Hernández-Ruiz ME, et al: Epithelial to mesenchymal transition markers are associated with an increased metastatic risk in primary cutaneous squamous cell carcinomas but are attenuated in lymph node metastases. J Dermatol Sci 72: 93-102, 2013

37. Aokage K, Ishii G, Ohtaki Y, et al: Dynamic molecular changes associated with epithelial-mesenchymal transition and subsequent mesenchymal-epithelial transition in the early phase of metastatic tumor formation. Int J Cancer 128: 1585-1595, 2011. 